\title{
CLINICAL IMPORTANCE OF EXPRESSION OF BIRC5 AND HER2-NEU GENES IN CIRCULATING TUMOR CELLS AS MARKERS OF MINIMUM RESIDUAL DISEASE IN SURGICAL TREATMENT OF BREAST CANCER
}

\author{
Vitebsk State Medical University, Vitebsk, \\ The Republic of Belarus
}

Цель. Оценить клиническое значение экспрессии генов BIRC5 и HER2-neu в циркулирующих опухолевых клетках как маркеров минимальной остаточной болезни на этапе хирургического лечения рака молочной железы.

Материал и методы. В исследовании приняли участие 162 пациентки с верифицированным первичным неметастатическим раком молочной железы (РМЖ) I-IIIC стадии в возрасте 58,2 $\pm 9,9$ года. Всем женщинам были выполнены операции в объеме радикальной мастэктомии по Маддену - $113(69,8 \%)$ и в объеме радикальной резекции молочной железы - 49 (30,2\%). У всех пациенток в день операции, а также на 2-е сутки после операции исследовалась периферическая кровь на наличие циркулирующих опухолевых клеток (ЦОК). Для идентификации ЦОК изучали экспрессию генов BIRC5 и HER2-neu, используя методику ПЦР в режиме реального времени.

Результаты. Положительные мРНК ВIRC5 и мРНК HER2-neu ЦОК до оперативного вмешательства были обнаружены у 115 женщин (71\%). После операции таргетные ЦОК исчезли у 47 (40,9\%) пациенток, у 59 женщин $(51,3 \%)$ ЦОК сохранились, а у 9 пациенток $(7,8 \%)$ после операции ЦОК впервые стали идентифицироваться в образцах венозной крови. После радикальной мастэктомии по Маддену частота сохранения таргетных ЦОК была достоверно ниже, чем после радикальной резекции молочной железы, и составила 46,9\% против $61,8 \%(\mathrm{p}=0,039)$. Частота сохранения таргетных ЦОК после операции была достоверно больше при ранних стадиях (I-IIA) без поражения регионарных лимфоузлов $-66,2 \%$, чем в более продвинутых стадиях (IIB-IIIC) $-45,0 \%$.

Заключение. Определение экспрессии гена BIRC5 и HER2-neu в обогащенном образце периферической крови является достоверным идентификатором циркулирующих опухолевых клеток и маркером минимальной остаточной болезни. Ранняя диссеминация опухолевых клеток способствует их сохранению в периферической крови пациенток до 51,3\%, несмотря на проведенное хирургическое вмешательство.

Ключевые слова: рак молочной железы, минимальная остаточная болезнь, циркулирующие опухолевые клетки, сурвивин, рецептор эпидермального фактора роста

Objective. To evaluate the clinical significance of the expression of BIRC5 and HER2-neu genes in circulating tumor cells as markers of minimal residual disease at the stage of surgical treatment of breast cancer.

Methods. 162 patients with the verified breast cancer of the I-IIIC stage aged 58.16 \pm 9.98 years took part in the study. All women underwent surgery in the amount of a Madden radical mastectomy - $113(69.8 \%)$ or radical resection $-49(30.2 \%)$. All patients on the day of surgery and also on the 2 nd day after the operation were examined for the presence of circulating tumor cells (CTCs) in the peripheral blood. For the identification of CTCs, expression of the BIRC5 and HER2-neu genes was studied using real-time polymerase chain reaction (RT-PCR).

Results. Positive mRNAs BIRC5 and HER2-neu CTCs before the surgery were detected in 115 women (71\%). After the operation, CTCs disappeared in 47 (40.9\%) patients, in $59(51.3 \%)$ CTCs were preserved, and in $9(7.8 \%)$ CTCs were first identified in the venous blood. After mastectomy the frequency of preservation of CTCs was significantly lower than after radical resection and was $46.9 \%$ compared to $61.8 \%$ ( $p=0.039$ ). The frequency of preservation of CTCs after surgery was significantly higher in the early stages (I-IIA) $-66.2 \%$ than in more advanced stages (IIB-IIIC) $-45.0 \%$.

Conclusions. Determination of the expression of the BIRC5 and HER2-neu gene in the enriched peripheral blood sample is a reliable identifier of the CTCs and the minimal residual disease marker. Early dissemination of tumor cells helps maintain CTCs in the peripheral blood of patients to $51.3 \%$, despite the surgical intervention.

Keywords: breast cancer, minimal residual disease, circulating tumor cells, survivin, epidermal growth factor receptor

Novosti Khirurgii. 2018 Jul-Aug; Vol 26 (4): 457-464

Clinical Importance of Expression of BIRC5 and HER2-Neu Genes in Circulating Tumor Cells as Markers of Minimum Residual Disease in Surgical Treatment of Breast Cancer

Ya. A. Shliakhtunou

Научная новизна статьи

Впервые с использованием метода молекулярно-генетического анализа получены новые данные о клини- 
ческом значении экспрессии генов BIRC5 и HER2-neu в циркулирующих опухолевых клетках как индикаторов минимальной остаточной болезни на этапе хирургического лечения первичного неметастатического рака молочной железы. Установлено, что ранняя диссеминация опухолевых клеток при данной патологии способствует сохранению циркулирующих опухолевых клеток, экспрессирующих гены BIRC5 и HER2-neu, в периферической крови до 51,3\%, несмотря на проведенное оперативное вмешательство.

\section{What this paper adds}

For the first time using the method of molecular genetic analysis new data were obtained about the clinical significance of the expression of BIRC5 and HER2-neu genes in circulating tumor cells as indicators of minimal residual disease at the stage of surgical treatment of primary non-metastatic breast cancer. It is determined that early dissemination of tumor cells in this pathology promotes the preservation of circulating tumor cells expressing the BIRC5 and HER2-neu genes in peripheral blood up to $51.3 \%$, despite the operative intervention.

\section{Introduction}

Breast cancer $(\mathrm{BC})$ is one of the most frequent oncological pathologies. Over the past decades, in most developed and developing countries of the world, there has been a steady increase in the incidence of this pathology. It occupies one of the first places among malignant neoplasms in women.

Experience shows that in case of resectable early non-metastatic breast cancer after a radical treatment metastasis occurs in almost half of patients during the first five years, regardless of regional lymph node involvement [1].

At present, metastatic breast cancer is incurable, and metastases result in death of the majority of patients with cancer. In this context, the problem of a possible relapse comes to the fore and, in turn, underscores the importance of minimal residual disease (MRD).

MRD is defined as the presence of tumor cells in the body that cannot be detected using today's routine diagnostic methods used to determine the stage of the tumor process in cancer patients after surgical removal of the primary tumor.

Typically, most relapses occur within the first 5 years after diagnosis and special treatment. However, even in the case of cure, the risk of progression persists. This fact is confirmed by the fact that on autopsy in patients who "survived" breast cancer, hidden metastases were discovered, which during their life were not diagnosed by conventional imaging methods. This, along with an understanding of the metastatic process, is the fundamental basis for the study of MRD in breast cancer [2].

It should be noted that circulating tumor cells (CTCs) are proposed to be classified as MRD [3]. The study of the tumor process dynamics allowed many scientists concluding that breast cancer is an initially disseminated tumor process, even at a preclinical stage, which cannot be diagnosed by traditional survey methods. And CTCs are a direct substratum of distant metastases [4].

Professor K.H. Bauer, who founded the German Center for Cancer Research, wrote in 1963 that "from the surgeon's point of view, surgery for cancer can be called radical only if even single cancer cells are removed from the body" [5].

Taking into account this statement, it is very important to understand the role and place of the surgical stage in the treatment of breast cancer, taking into account the presence of CTCs both before the start of a special treatment for primary non-metastatic breast cancer and their possible preservation after the operation. It is very important in the context of the CTCs search to look for universal markers and to improve the methods for identifying the latter. Taking into account this issue, such genes as the gene of the anti-apoptotic protein survivin BIRC5 and the gene of the epidermal growth factor receptor HER2-neu can be considered as potential markers for the identification of CTCs.

Objective. To evaluate the clinical significance of the expression of BIRC5 and HER2-neu genes in circulating tumor cells as markers of minimal residual disease at the stage of surgical treatment of breast cancer.

\section{Methods}

162 patients with the verified primary nonmetastatic breast cancer being treated in Vitebsk Regional Clinical Oncology Center during 20152016 participated in the survey study. The mean age of patients was $58.2 \pm 9.9(\mathrm{M} \pm \mathrm{SD})$ with individual fluctuations from 31 to 91 years.

The clinical characteristics of the tumor process are presented in Tables 1 and 2.

All women underwent surgery in the amount of Madden radical mastectomy - $113(69.8 \%)$ or radical resection of the breast $-49(30.2 \%)$.

The peripheral blood sample from the ulnar vein was taken in the morning on an empty stomach in a volume of $5 \mathrm{ml}$ in a sterile vacuum tube with K2EDTA for subsequent enrichment and isolation of the CTCs in all patients on the day of operation and on the $2^{\text {nd }}$ day after the operation and stored at $4^{\circ} \mathrm{C}$ before the study. Samples were processed immediately or no later than four hours after blood sampling.

Enrichment and isolation of CTCs was performed using the technology of rapid isolation of tumor cells from the whole blood on the basis of covalently bound antibodies for CD326 on a non- 
Table 1

Clinico-anatomical characteristics of the primary tumor $(n=162)$

\begin{tabular}{cccc}
\hline \multicolumn{2}{c}{ Category, value } & $\mathrm{n}$ & $\%$ \\
\hline $\mathrm{T}$ & 1 & 87 & 53.70 \\
& 2 & 70 & 43.21 \\
& 3 & 4 & 2.47 \\
& 4 & 1 & 0.62 \\
\hline $\mathrm{N}$ & 0 & 78 & 48.15 \\
& 1 & 63 & 38.89 \\
& 2 & 7 & 4.32 \\
& 3 & 14 & 8.64 \\
\hline Stage & I & 54 & 33.33 \\
& IIA & 54 & 33.33 \\
& IIB & 28 & 17.28 \\
& IIIA & 8 & 4.94 \\
& IIIB & 1 & 0.62 \\
& IIIC & 15 & 9.26 \\
\hline
\end{tabular}

magnetic polymeric matrix of large microspheres followed by isolation of CTCs according to size (S-pluriBead Maxi Reagent Kit and anti-human CD326 S- pluriBead, Germany).

Isolation of mRNA from lysed, enriched cells was carried out in accordance with the instructions of the manufacturer of RNA isolation kits (SIVital, Belarus). Using reverse transcription technology, a cDNA was synthesized, which was used subsequently to analyze gene expression in real time. To test the expression of the HER2-neu and BIRC5 genes, original test systems were used to determine the expression of survivin and Her2neu transcription cDNA by the RT-PCR method (SIVital, Belarus).

\section{Statistics}

Statistical processing of data was carried out in accordance with modern requirements for conducting biomedical research. Qualitative indicators are represented by absolute and relative values.

When checking the distribution for the normality of quantitative characteristics by the criteria of Lilliefors and Shapiro-Wilk, it was found out that the quantitative characteristics do not obey the normal distribution law. Characteristics of these quantitative characteristics are presented as a median (Me), interquartile range (LQ / UQ), minimum and maximum values (min, $\max$ ).

When comparing the pre- and postoperative indicators, the Wilcoxon test was used. Comparison of qualitative nominative data was carried out using the Pearson chi-square (2) criterion, by qualitative binary - using the 2 criteria with the Yates's correction and the exact Fisher criterion in accordance with the conditions of their applicability.

In all cases, the differences were considered statistically significant at a significance level of $\mathrm{p}$ $<0.05$.

\section{Results}

Positive BIRC5 mRNA and positive HER2neu mRNA of CTCs before surgery were detected in 115 women $(71 \%)$ out of 162 patients with the verified primary non-metastatic breast cancer. The study in dynamics of the presence and identification of CTCs on two targeted genetic markers BIRC5 and HER2-neu after surgery revealed some interesting facts. So, after the operation, BIRC5 mRNA positive and HER2-neu

Pathomorphological characteristics of the primary tumor $(n=162)$

\begin{tabular}{|c|c|c|c|}
\hline \multicolumn{2}{|c|}{ Category, value } & $\mathrm{n}$ & $\%$ \\
\hline \multirow[t]{6}{*}{ Morphological structure of carcinoma } & tubular & 1 & 0.62 \\
\hline & medullar & 3 & 1.85 \\
\hline & mucinous & 3 & 1.85 \\
\hline & non-specific & 22 & 13.58 \\
\hline & lobular & 34 & 20.99 \\
\hline & ductal & 99 & 61.11 \\
\hline \multirow[t]{3}{*}{ Degree of differentiation } & G1 & 5 & 3.09 \\
\hline & G2 & 71 & 43.83 \\
\hline & G3 & 86 & 53.09 \\
\hline \multirow[t]{2}{*}{ Lympho-venous-vascular invasion } & LVSI+ & 136 & 83.95 \\
\hline & LVSI- & 26 & 16.05 \\
\hline \multirow[t]{5}{*}{ Molecular-biological tumor subtype } & luminal $\mathrm{A}$ & 79 & 48.77 \\
\hline & luminal BHER2- & 41 & 25.31 \\
\hline & Luminal B HER2+ & 9 & 5.56 \\
\hline & hyper HER2 expressing & 11 & 6.79 \\
\hline & triple negative (basal) & 22 & 13.58 \\
\hline
\end{tabular}


mRNA positive CTCs disappeared in $47(40.9 \%)$ of the patients in whom they were originally identified. In more than half of the cases - in 59 $(51.3 \%)$ - the identified CTCs were preserved in the peripheral blood. Moreover, in 9 patients (7.8\%) after the operation, CTCs were identified in the enriched venous blood samples (Table 3).

Dynamics of changes in the frequency of identification of target CTCs has been found out to have certain regularities depending on the volume of the surgical operation. So, after Madden radical mastectomy, the frequency of preservation of CTC was significantly lower than after the radical breast resection and was $46.9 \%$ compared to $61.8 \%$ $(\mathrm{p}=0.039)$ (Table 4).

When analyzing the amount of expressed target genes in the CTCs after the operation, in comparison with the data obtained before the beginning of the special treatment while studying the peripheral blood of patients with the verified primary non-metastatic breast cancer, a significant difference was obtained. For example, there was a statistically significant reduction in the incidence of simultaneous expression of two genes from $72.1 \%$ to $29.4 \%$, with a simultaneous increase in the frequency of identification of the CTCs in one of the BIRC5 or HER2-neu genes (Table 5).

With qualitative analysis of the levels of the normalized expression of targeted genes in the CTCs, significant differences in the expression level were not established at the stage of surgical treatment (Table 6).

Comparative analysis of the preservation incidence of BIRC5 positive mRNA and HER2-neu positive mRNA CTCs in the enriched peripheral blood samples of patients before and after surgery, depending on the stage of the tumor process (pTNM), yielded some interesting data. Paradoxical as it may seem, the frequency of conservation of targeted CTCs after surgery in the early stages (I-IIA) without lesion of the regional lymph nodes was statistically significantly $(\mathrm{p}<0.05)$ higher and was $66.2 \%$ than after operations for locally advanced tumor process (IIB-IIIC), where this indicator was $45.0 \%$ (Table 7).

The dynamics of changes in the frequency of the identification of BIRC5 mRNA positive and HER2-neu mRNA positive CTCs at the stage of surgical treatment

\begin{tabular}{|c|c|c|c|c|c|c|c|c|}
\hline \multirow[t]{4}{*}{$\mathrm{n}$} & \multicolumn{8}{|c|}{ CTCs identification incidence } \\
\hline & \multirow{2}{*}{\multicolumn{2}{|c|}{$\begin{array}{c}\text { Before surgery } \\
\text { Presence of } \\
\text { mRNA BIRC5 + mRNA } \\
\text { HER2-neu + CTCs }\end{array}$}} & \multirow{2}{*}{\multicolumn{2}{|c|}{$\begin{array}{c}\text { mRNA BIRC5 + mRNA } \\
\text { HER2-neu + CTCs, CTCs } \\
\text { disappeared }\end{array}$}} & \multirow{2}{*}{\multicolumn{2}{|c|}{$\begin{array}{c}\text { After surgery } \\
\text { mRNA BIRC5 }+ \\
\text { mRNA HER2-neu }+ \\
\text { CTCs, CTCs preserved }\end{array}$}} & \multirow{2}{*}{\multicolumn{2}{|c|}{$\begin{array}{c}\text { mRNA BIRC5 + } \\
\text { mRNA HER2-neu + } \\
\text { CTCs, CTCs appeared }\end{array}$}} \\
\hline & & & & & & & & \\
\hline & abs & $\%$ & abs & $\%$ & abs & $\%$ & abs & $\%$ \\
\hline 162 & 115 & $71.0 \%$ & 47 & $40.9 \%$ & 59 & $51.3 \%$ & 9 & $7.8 \%$ \\
\hline
\end{tabular}

Table 4

The dynamics of changes in the frequency of the identification of BIRC5 mRNA positive and HER2-neu mRNA positive CTCs depending on the volume of surgical treatment

\begin{tabular}{|c|c|c|c|c|c|c|c|c|c|}
\hline \multirow[t]{4}{*}{ Surgery volume } & \multirow[t]{4}{*}{$\mathrm{n}$} & \multicolumn{8}{|c|}{ Identification incidence of CTCs } \\
\hline & & \multirow{2}{*}{\multicolumn{2}{|c|}{$\begin{array}{c}\text { Before surgery } \\
\text { Presence of } \\
\text { BIRC5 + HER2- } \\
\text { neu + CTCs }\end{array}$}} & \multicolumn{6}{|c|}{ After surgery } \\
\hline & & & & \multicolumn{2}{|c|}{$\begin{array}{c}\text { BIRC5 + } \\
\text { HER2-neu + CTCs } \\
\text { disappeared }\end{array}$} & \multicolumn{2}{|c|}{$\begin{array}{c}\text { BIRC5 + } \\
\text { HER2-neu + } \\
\text { CTCs preserved }\end{array}$} & \multicolumn{2}{|c|}{$\begin{array}{c}\text { BIRC5 + HER2- } \\
\text { neu + CTCs } \\
\text { appeared }\end{array}$} \\
\hline & & abs & $\%$ & abs & $\%$ & abs & $\%$ & abs & $\%$ \\
\hline $\begin{array}{l}\text { Radical mastectomy } \\
\text { according to Madden }\end{array}$ & 113 & 81 & 71.7 & 35 & 43.2 & 38 & 46.9 & 8 & 9.9 \\
\hline \multirow[t]{2}{*}{ Radical resection } & 49 & 34 & 69.4 & 12 & 35.3 & 21 & 61.8 & 1 & 2.9 \\
\hline & $\mathrm{P}$ & & & \multicolumn{2}{|c|}{0.283} & \multicolumn{2}{|c|}{0.105} & \multicolumn{2}{|c|}{0.204} \\
\hline
\end{tabular}

Table 5

The number of expressed genes in CTCs enriched and isolated in patients before surgery and preserved after surgery $(n=68)$

\begin{tabular}{|c|c|c|c|c|c|}
\hline \multirow[t]{2}{*}{$\begin{array}{l}\text { The number of expressed } \\
\text { genes }\end{array}$} & \multicolumn{4}{|c|}{$\begin{array}{l}\text { Identification incidence of BIRC5 and Her2 genes expression } \\
\text { Before surgery }\end{array}$} & \multirow[t]{2}{*}{$\mathrm{p}$} \\
\hline & abs & $\%$ & abs & $\%$ & \\
\hline 2 genes & 49 & $72.1 \%$ & 20 & $29.4 \%$ & 0.0000 \\
\hline 1 gene BIRC5 & 6 & $8.8 \%$ & 25 & $36.8 \%$ & 0.0001 \\
\hline 1 gene HER2-neu & 13 & $19.1 \%$ & 23 & $33.8 \%$ & 0.0397 \\
\hline
\end{tabular}


The parameters of the normalized expression of target genes determined in the CTCs by the RT-PCR method in real time $(n=68)$

\begin{tabular}{llcccccc}
\hline $\begin{array}{l}\text { Genetic marker of } \\
\text { CTCs }\end{array}$ & $\begin{array}{c}\text { Determination } \\
\text { time }\end{array}$ & \multicolumn{6}{c}{ The parameters of the normalized expression of } \\
& & Median & Min & Max & LQ & UQ & \\
\hline BIRC5 & Before surgery & 0.144 & 0.001 & 10.7 & 0.006 & 0.455 & 0.209 \\
& After surgery & 0.387 & 0.001 & 8.72 & 0.113 & 1.053 & \\
HER2-neu & Before surgery & 0.258 & 0.021 & 17.44 & 0.121 & 1.327 & 0.614 \\
& After surgery & 0.207 & 0.258 & 9.09 & 0.111 & 0.830 & \\
\hline
\end{tabular}

Table 7

The incidence of minimal residual disease at the stage of surgical treatment, depending on the stage of the tumor process

\begin{tabular}{|c|c|c|c|c|c|c|c|c|}
\hline \multirow{3}{*}{\multicolumn{2}{|c|}{ Category, value }} & \multirow[t]{3}{*}{$\mathrm{n}$} & \multicolumn{5}{|c|}{ Identification incidence of CTCs } & \multirow[t]{3}{*}{$\mathrm{p}$} \\
\hline & & & \multicolumn{2}{|c|}{$\begin{array}{l}\text { BIRC5 and Her2-neu+ } \\
\text { CTCs before surgery }\end{array}$} & \multicolumn{3}{|c|}{$\begin{array}{l}\text { BIRC5 и Her2-neu }+ \\
\text { CTCs after surgery }\end{array}$} & \\
\hline & & & abs., n1 & $\%$ of $n$ & abs., n2 & $\%$ of $n 1$ & $\%$ of $n 2$ & \\
\hline $\mathrm{n}$ & & 162 & 115 & 71.0 & 68 & 42.0 & 59.1 & \multirow{3}{*}{$\begin{array}{l}0.632(\mathrm{n} 1-\mathrm{n} 2) \\
0.171(\mathrm{n}-\mathrm{n} 2)\end{array}$} \\
\hline \multirow[t]{2}{*}{$\mathrm{T}$} & 1 & 87 & 60 & 69.0 & 40 & 46.0 & 66.7 & \\
\hline & $2-4$ & 75 & 55 & 73.3 & 28 & 37.3 & 50.9 & \\
\hline \multirow[t]{2}{*}{$\mathrm{N}$} & 0 & 78 & 50 & 64.1 & 31 & 39.7 & 62.0 & \multirow{2}{*}{$\begin{array}{l}0.360(\mathrm{n} 1-\mathrm{n} 2) \\
0.346(\mathrm{n}-\mathrm{n} 2)\end{array}$} \\
\hline & $1-3$ & 84 & 65 & 77.4 & 37 & 44.0 & 56.9 & \\
\hline \multirow[t]{2}{*}{ Stage } & I-IIA & 108 & 74 & 68.5 & 49 & 45.4 & 66.2 & \multirow{2}{*}{$\begin{array}{l}0.023(\mathrm{n} 1-\mathrm{n} 2) \\
0.096(\mathrm{n}-\mathrm{n} 2)\end{array}$} \\
\hline & IIB-IIIC & 54 & 40 & 74.1 & 18 & 33.3 & 45.0 & \\
\hline
\end{tabular}

Note: $\mathrm{n} 1$ - is the absolute amount of BIRC5 mRNA and Her2-neu mRNA of positive CTCs cases before surgery, $\mathrm{n} 2-$ is the absolute amount of BIRC5 mRNA and Her2-neu mRNA of positive CTCs cases after surgery.

This fact can be explained by a possible reduction in the volume of surgery in the early stages before radial resection (quadrantectomy, lumpectomy) and the possible option of preserving tumor cells within the remaining part of the mammary gland that are the source of the CTCs.

In a comparative analysis of the preservation incidence of BIRC5 mRNA positive and HER2-neu mRNA positive CTCs in the enriched peripheral blood samples of patients before and after surgery depending on the pathomorphological and molecular biological characteristics of the tumor, the following data were obtained. So the frequency of CTCs preservation in the body of a woman after surgery did not depend on the histological structure of the primary tumor. At the same time, it depended on the degree of differentiation of the carcinoma. The frequency of CTCs identification after surgery was $10.3 \%$ higher at a low degree of differentiation (G3) than in highly differentiated tumors (G1), and amounted to $60.3 \%$ and $50 \%$, respectively $(p=0.029)$. Statistically significant differences were not established in the frequency of presence of CTCs after radical surgical treatment, depending on the presence or absence of the tumor lympho-vascular stromal invasion (LVSI).

An important point in this fragment of the study is the fact that the detection incidence of positive BIRC5 mRNA and positive HER2-neu mRNA in the enriched peripheral blood samples of patients after radical mastectomy or radical resection depend significantly on the molecular-biological tumor subtype.

A verified change in the frequency of CTCs identification toward the decrease after surgery was established in case of luminal A and luminal B HER2 non-expressing cancers (Table 8). With other molecular-biological subtypes of breast cancer, there was no significant reduction in the frequency of identification of CTCs in the targeted genes. This situation indicates a possible more favorable course of the first two forms of breast cancer and the beneficial effect of surgical intervention.

However, in a comparative analysis of the incidence of CTCs preservation in the peripheral blood, no significant differences were found depending on the tumor subtype.

\section{Discussions}

Back in 1929 Ya.V. Zilberberg, admitting the possibility of hematogenous spread of breast cancer cells, attributed the importance of a factor contributing to the massive admission of tumor cells into the blood, and B.T. Bilinsky in 1963 published data that local relapses developed in $13.3 \%$ of women operated on for breast cancer, with most relapses occurring during the first 2 years 


\begin{tabular}{|c|c|c|c|c|c|c|c|}
\hline \multirow{4}{*}{$\begin{array}{l}\text { Molecular-biological subtype } \\
\text { of the tumor }\end{array}$} & \multirow{4}{*}{$\begin{array}{c}\mathrm{n} \\
162\end{array}$} & \multicolumn{5}{|c|}{ Incidence of CTCs identification } & \multirow[t]{4}{*}{$\mathrm{p}$} \\
\hline & & \multicolumn{2}{|c|}{$\begin{array}{l}\text { BIRC5 и Her2-neu + } \\
\text { CTCs before surgery }\end{array}$} & \multicolumn{3}{|c|}{$\begin{array}{c}\text { BIRC5 и Her2-neu + } \\
\text { CTCs after surgery }\end{array}$} & \\
\hline & & abs., n1 & $\%$ of $n$ & abs., n2 & $\%$ of $n 1$ & $\%$ of $n 2$ & \\
\hline & & 115 & 71.0 & 68 & 42.0 & 59.1 & \\
\hline luminal A & 79 & 57 & 72.2 & 32 & 40.5 & 56.1 & 0.000 \\
\hline Luminal B HER2- & 41 & 29 & 70.7 & 18 & 43.9 & 62.1 & 0.012 \\
\hline Luminal B HER2+ & 9 & 6 & 66.7 & 4 & 44.4 & 66.7 & 0.319 \\
\hline hyper HER2 expressing & 11 & 7 & 63.6 & 4 & 36.4 & 57.1 & 0.197 \\
\hline triple negative & 22 & 16 & 72.7 & 10 & 45.5 & 62.5 & 0.062 \\
\hline
\end{tabular}

Note: $\mathrm{n} 1$ - is the absolute amount of BIRC5 mRNA and Her2-neu mRNA of positive CTC cases before surgery, $\mathrm{n} 2$ - is the absolute amount of BIRC5 mRNA and Her2-neu mRNA of positive CTC cases after surgery.

after surgery [6, 7]. A specially conducted study in animals allowed establishing the pathogenetic role of the cellular microenvironment during the healing of an operating wound in the development of local tumor recurrence, which is caused by the involvement of tumor cells circulating in the peripheral blood to the site of wound healing [8].

In our study, taking into account the data on the presence of functionally active heterogeneous CTCs in the peripheral blood before the start of the special treatment and mainly before the operation, it should be noted that non-surgical intervention leads to massive admission of tumor cells into the blood, and early tumor dissemination takes place before the onset of surgical stage of treatment. On the contrary, radical surgical intervention significantly reduces the amount of CTCs in the peripheral blood, which was demonstrated in the postoperative period.

According to the literature, the "massage" of the tumor results in at least a 10-fold increase in the number of tumor cells leaving the primary tumor site, and surgical manipulations in breast tumors can induce angiogenesis and proliferation of cells of distant "dormant" micrometastases, especially in young patients with positive lymph nodes $[6,7$, 9, 10, 11, 12].

According to the obtained data, the amount of surgery affects the frequency of preservation of CTCs in the peripheral blood. But, paradoxically, after a less traumatic operation, such as radical resection, the frequency of preservation of CTCs was significantly higher than after a large traumatic operation with large tissue damage - a Madden radical mastectomy, in which the tumor is much more exposed to "massage."

One should also take into account the phenomenon of "dumping" of tumor cells from the primary node, which is associated with angiogenesis in the tumor, vascular invasion, tumor size and its proliferative potential [3]. It is established that tumor cells can leave the growing tumor node at a rate ranging from several thousand to several million

\section{cells per day per $1 \mathrm{~g}$ of tissue [13].}

Studies have shown that the preservation and appearance in the peripheral bloodstream of the CTCs of expression genes, the anti-apoptotic protein and epidermal growth factor receptor depends on tumor size, regional lymph node involvement. An important fact is the establishment of the regularity of the detection incidence of CTCs from the molecular-biological subtype of the primary tumor, which is associated with both the expression of estrogen and progesterone receptors, and with the expression of the HER2-neu oncoprotein and the index of $\mathrm{Ki}-67$ proliferative activity.

Despite the fact that most tumors can be subjected to radical surgery, the so-called resection of $\mathrm{R} 0$, in a significant number of patients after a certain time, distant metastases appear. The reason for this is pre- or postoperative dissemination of tumor cells that were not detected at the time of the surgical operation [14]. Over 20 years ago, these cells, or clusters, were called micrometastases and were included in the TNM system of the 6th edition (2002) and were left in the $7^{\text {th }}$ (2009), receiving the following notation according to the pM category: isolated tumor cells found in bone marrow with the help of histological methods, $-\mathrm{M} 0(\mathrm{i}+)$; with the help of non-histological (in other words, molecular) methods - M0 $(\mathrm{mol}+)$ [15]. In fact, these cells are called isolated or disseminated depending on their presence in the blood or bone marrow; the presence of such cells in the body of an oncological patient is regarded as MRD.

Taking into account this classification, most patients can be exposed to the stage M0 $(\mathrm{mol}+)$, namely, with the regard to the data obtained, $71.0 \%$ before surgery and $42.0 \%$ after surgery.

\section{Conclusions}

Determination of the expression of the gene survivin BIRC5 and the epidermal growth factor receptor gene HER2-neu in the enriched peripheral 
blood sample is a reliable identifier of the CTCs and the marker of the MRD.

Early dissemination of tumor cells in primary non-metastatic breast cancer, confirmed by the presence of BIRC5 mRNA and HER2-neu mRNA positive CTCs in $71 \%$, promotes maintenance of CTCs in the peripheral blood up to $51.3 \%$ of patients despite surgical interventions. In some cases, surgery contributes to the emergence of new tumor cells in the peripheral bloodstream (7.8\%).

The volume of the operation affects the preservation of the CTCs in the peripheral blood. After Madden radical mastectomy, the incidence of CTCs preservation was significantly lower than after the radical breast resection and was $46.9 \%$ versus $61.8 \%(\mathrm{p}=0.039)$.

The contributing factors for the preservation of functionally active CTCs expressing tumorspecific genes encoding the anti-apoptotic peptide survivin and the epidermal growth factor receptor that provide an aggressive phenotype of these cells, which are the source of metastases, are the stage of the tumor process, and besides, at the early stages the identification incidence of CTCs is significantly higher and is $45.4 \%$ for I-IIA and $33.3 \%$ for IIBIIIC, respectively $(p=0.023)$. The frequency of the targeted CTCs in case of luminal A and luminal B not expressing HER2-neu subtypes of breast cancer decreases reliably from $72.2 \%$ to $40.5 \%$ (p $=0.000)$ and from $70.7 \%$ to $43.9 \%(p=0.012)$, respectively. The frequency of preservation of CTCs in the peripheral blood after the operation does not depend on the molecular-biological subtype of the primary breast carcinoma.

\section{Information about the source of support in the form of grants, equipment, medicines}

The work was carried out in accordance with the plan of scientific works of Vitebsk State Medical University. The authors did not receive any financial support from the manufacturers of medicines.

\section{Conflict of interest}

The authors declare that they have no conflict of interest.

\section{Ethics Committee approval}

Approved by the Ethics Committee of Vitebsk State Medical University, as well as by the Ethics Committee of Vitebsk Regional Clinical Oncology Center.

\section{ЛИТЕРАТУРА}

1. Senkus E, Kyriakides S, Ohno S, Penault-Llorca
F, Poortmans P, Rutgers E, Zackrisson S, Cardoso F. Primary breast cancer: ESMO Clinical Practice Guidelines for diagnosis, treatment and follow-up. ESMO Guidelines Committee. Ann Oncol. 2015;26 (5):v8-30. doi: $10.1093 /$ annonc/mdv298

2. Cheng L, Swartz MD, Zhao H, Kapadia AS, Lai D, Rowan PJ, Buchholz TA, Giordano SH (2012) Hazard of recurrence among women after primary breast cancer treatment-a 10-year follow- up using data from SEER-Medicare. Cancer Epidemiol Biomark Prev. 2012; 21(5):800-809. doi: 10.1158/1055-9965. EPI-11-1089

3. Pantel K, Alix-Panabières C, Riethdorf. Cancer micrometastases. Nature Reviews Clinical Oncology. 2009;6(6):339-51. doi:10.1038/nrclinonc.2009.44

4. Onstenk W, Gratama JW, Foekens JA, Sleijfer S. Towards a personalized breast cancer treatment approach guided by circulating tumor cell (CTC) characteristics. Cancer Treat. Rev. 2013;39(7):691-700. doi:10.1016/j.ctrv.2013.04.001

5. Tonak J, Gall FP, Hohenberge W, Hermanek P, Mbhe E, Angermann B. Prinzipien der chirurgie maligner tumoren. In: Gall FP, Hermanek P, Tonak J, editors. Chirurgische Onkologie. Springer Link; 1986. p. 131-53. https://link.springer.com/chapter/10.1007/978-3-642-69600-8 8

6. Miller MC, Doyle GV, Terstappen LW. Significance of Circulating Tumor Cells Detected by the CellSearch System in Patients with Metastatic Breast Colorectal and Prostate Cancer. J Oncol. 2010;2010:617421. doi: $10.1155 / 2010 / 617421$

7. Swaby RF, Cristofanilli M. Circulating tumor cells in breast cancer: a tool whose time has come of age. $B M C$ Med. 2011;9:43. doi.org/10.1186/1741-7015-9-43.

8. Antonio N, Bwnnelykke-Behrndtz ML, Ward LC, Collin J, Christensen IJ, Steiniche T, Schmidt H, Feng $\mathrm{Y}$, Martin1 P. The wound inflammatory response exacerbates growth of pre-neoplastic cells and progression to cancer. EMBO J. 2015;2; 34(17):2219-36. doi:10.15252/embj.201490147

9. Makki J. Diversity of breast carcinoma: histological subtypes and clinical relevance. Clin Med Insights Pathol. 2015;8:23-31. doi: 10.4137/CPath.S31563

10. Toss A, Cristofanilli M. Molecular characterization and targeted therapeutic approaches in breast cancer. Breast Cancer Res. 2015;17(1):60 https://doi. org/10.1186/s13058-015-0560-9

11. Sleeman JP, Christofori G, Fodde R, Collard JG, Berx G, Decraene C, Ruegg C. Concepts of metastasis in flux: the stromal progression model. Semin Cancer Biol. 2012;22(3):174-186. doi:10.1016/j.semcancer.2012.02.007.

12. Wu S, Liu S, Liu Z, Huang J, Pu X, Li J, Yang D, Deng H, Yang N, Xu J. Classification of circulating tumor cells by epithelial-mesenchymal transition markers. PLoS One. 2015;24;10(4):e0123976. doi:10.1371/ journal.pone. 0123976

13. Smerage JB, Barlow WE, Hortobagyi GN, Winer EP, Leyland- Jones B, Srkalovic G, Tejwani S, Schott AF, O'Rourke MA, Lew DL, Doyle GV, Gralow JR, Livingston RB, Hayes DF. Circulating tumor cells and response to chemotherapy in metastatic breast cancer: SWOG S0500. J Clin Oncol. 2014;32(31):3483-89. doi:10.1200/JCO.2014.56.2561.

14. Patel P, Chen EI. Cancer stem cells, tumor dormancy, and metastasis. Front Endocrinol (Lausanne). 2012;23;3:125. doi: 10.3389/fendo.2012.00125

15. Saadatmand S, Bretveld R, Siesling S, Tilanus- 
Linthorst MM. Influence of tumour stage at breast cancer detection on survival in modern times: population based study in 173,797 patients. BMJ (Clinical research ed). 2015;351:h4901. doi:10.1136/ bmj.h4901

\section{REFERENCES}

1. Senkus E, Kyriakides S, Ohno S, Penault-Llorca F, Poortmans P, Rutgers E, Zackrisson S, Cardoso F. Primary breast cancer: ESMO Clinical Practice Guidelines for diagnosis, treatment and follow-up. ESMO Guidelines Committee. Ann Oncol. 2015;26 (5):v8-30. doi: 10.1093/annonc/mdv298

2. Cheng L, Swartz MD, Zhao H, Kapadia AS, Lai D, Rowan PJ, Buchholz TA, Giordano SH (2012) Hazard of recurrence among women after primary breast cancer treatment-a 10-year follow- up using data from SEER-Medicare. Cancer Epidemiol Biomark Prev. 2012; 21(5):800-809. doi: 10.1158/1055-9965. EPI-11-1089

3. Pantel K, Alix-Panabières C, Riethdorf. Cancer micrometastases. Nature Reviews Clinical Oncology. 2009;6(6): 339-51. doi:10.1038/nrclinonc.2009.44.

4. Onstenk W, Gratama JW, Foekens JA, Sleijfer S. Towards a personalized breast cancer treatment approach guided by circulating tumor cell (CTC) characteristics. Cancer Treat. Rev. 2013;39(7):691-700. doi:10.1016/j.ctrv.2013.04.001

5. Tonak J, Gall FP, Hohenberge W, Hermanek P, Mьhe E, Angermann B. Prinzipien der chirurgie maligner tumoren. In: Gall FP, Hermanek P, Tonak J, editors. Chirurgische Onkologie. Springer Link; 1986. p. 131-53. https://link.springer.com/chapter/10.1007/978-3-642-69600-8_8

6. Miller MC, Doyle GV, Terstappen LW. Significance of Circulating Tumor Cells Detected by the CellSearch System in Patients with Metastatic Breast Colorectal and Prostate Cancer. J Oncol. 2010;2010:617421. doi: $10.1155 / 2010 / 617421$

7. Swaby RF, Cristofanilli M. Circulating tumor cells

\section{Адрес для корреспонденции}

210023, Республика Беларусь,

г. Витебск, пр. Фрунзе, 27,

Витебский государственный

медицинский университет,

кафедра онкологии с курсами

ЛД, ЛТ, ФПК и ПК,

тел. раб.:+375 212 57-64-16,

e-mail: Evgenij-shlyakhtunov@yandex.ru,

Шляхтунов Евгений Александрович

\section{Сведения об авторах}

Шляхтунов Евгений Александрович, к.м.н., доцент, доцент кафедры онкологии с курсами ЛД, ЛТ, ФПК и ПК УО «Витебский государственный медицинский университет», г. Витебск, Республика Беларусь. https://orcid.org/0000-0002-5906-5373

\section{Информация о статье}

Поступила 18 декабря 2017 г.

Принята в печать 7 мая 2018 г.

Доступна на сайте 30 август 2018 г. in breast cancer: a tool whose time has come of age. BMC Med. 2011;9:43. doi.org/10.1186/1741-7015-9-43 8. Antonio N, Bшnnelykke-Behrndtz ML, Ward LC, Collin J, Christensen IJ, Steiniche T, Schmidt H, Feng Y, Martin1 P. The wound inflammatory response exacerbates growth of pre-neoplastic cells and progression to cancer. EMBO J. 2015;2; 34(17):2219-2236. doi:10.15252/embj.201490147

9. Makki J. Diversity of breast carcinoma: histological subtypes and clinical relevance. Clin Med Insights Pathol. 2015;8:23-31. doi: 10.4137/CPath.S31563

10. Toss A, Cristofanilli M. Molecular characterization and targeted therapeutic approaches in breast cancer. Breast Cancer Res. 2015;17(1):60 https://doi. org/10.1186/s13058-015-0560-9

11. Sleeman JP, Christofori G, Fodde R, Collard JG, Berx G, Decraene C, Ruegg C. Concepts of metastasis in flux: the stromal progression model. Semin Cancer Biol. 2012; 22(3):174-86. doi:10.1016/j.semcancer.2012.02.007.

12. Wu S, Liu S, Liu Z, Huang J, Pu X, Li J, Yang D, Deng H, Yang N, Xu J. Classification of circulating tumor cells by epithelial-mesenchymal transition markers. PLoS One. 2015;24;10(4):e0123976. doi:10.1371/ journal.pone.0123976.

13. Smerage JB, Barlow WE, Hortobagyi GN, Winer EP, Leyland- Jones B, Srkalovic G, Tejwani S, Schott AF, O'Rourke MA, Lew DL, Doyle GV, Gralow JR, Livingston RB, Hayes DF. Circulating tumor cells and response to chemotherapy in metastatic breast cancer: SWOG S0500. J Clin Oncol. 2014;32(31):3483-89. doi:10.1200/JCO.2014.56.2561

14. Patel P, Chen EI. Cancer stem cells, tumor dormancy, and metastasis. Front Endocrinol (Lausanne). 2012;23;3:125. doi: 10.3389 /fendo.2012.00125

15. Saadatmand S, Bretveld R, Siesling S, TilanusLinthorst MM. Influence of tumour stage at breast cancer detection on survival in modern times: population based study in 173,797 patients. BMJ (Clinical research ed). 2015;351:h4901. doi:10.1136/ bmj.h4901

\section{Address for correspondence}

210023, The Republic of Belarus,

Vitebsk, Frunze Ave., 27,

Vitebsk State Medical University,

Department of Oncology

With the Courses

of RD, RT, FST and SRT,

Tel. office: +375 212 57-64-16,

e-mail: Evgenij-shlyakhtunov@yandex.ru,

Yauheni A. Shliakhtunou

\section{Information about the authors}

Shliakhtunou Yauheni A., PhD, Associate Professor of the Department of Oncology with the Courses of RD, RT, FST and SRT, Vitebsk State Medical University, Vitebsk, Republic of Belarus.

https://orcid.org/0000-0002-5906-5373

\section{Article history}

Arrived 18 December 2017

Accepted for publication 7 May 2018

Available online 30 August 2018 